\title{
A Conference on Security and Cooperation in the Middle East
}

\author{
Rene Wadlow
}

In a 26 June 2018 address to the United Nations Security Council, Antonio Guterres, the Secretary- General, reviewed the conflict situations in the Middle East - its profound divisions, troubling currents and the tragic shredding of its diverse religious, ethnic and cultural fabric. As he noted "In Syria, civilians have borne a litany of atrocities for more than seven years of conflict: sieges, starvation, indiscriminate attacks, the use of chemical weapons, exile and forced displacement, sexual violence, torture, detention and enforced disappearances." He called for renewed support for his Special Envoy, Staffan de Mistura, on the Syrian conflict and possible Geneva meetings.

Likewise, he called for support for the UN Special Envoy to Yemen, Martin Griffiths. What was new in the Secretary-General's presentation was to highlight the Helsinki process as a possible avenue for the Middle East. He said: "During the Cold War, ideological rivals found ways to talk and cooperate despite their deep divides, for example through the Helsinki process. I do not see why countries of the region cannot find a similar platform to come together, drawing experience from one another and enhancing opportunities for possible political, environmental, socio-economic or security cooperation."

The Association of World Citizens has for a good number of years proposed a Conference for Security and Cooperation in the Middle East, with full recognition of all States in the region with steps toward a Middle East Common Market, cooperation on water issues and the creation of a trans-frontier special economic zone for the Gaza strip. Such a Middle East Conference is based on the Helsinki Conference of 1973-1975.
When the first phase of the Conference on Security and Co-operation in Europe concluded in Helsinki in July 1973, some saw that seeds to end the Cold War had been planted, but that these seeds would have to be watered and carefully protected. The Helsinki Final Act was still unwritten and even the issues to be discussed had not yet been set out beyond a rather general and vague sentiment that military security and military confidencebuilding steps were important.

The negotiators moved to Geneva, Switzerland, and discussed from 18 September until the eve of the Summit, to be again held in Helsinki on 1 August 1975. As midnight of the deadline for agreeing on the text of the Helsinki Final Act was approaching, the clock in the meeting room was stopped so that the text could be finalized in the agreed time.

There were diplomats from three groups of States: the Western States, the Soviet Union and its allies, the four neutral States and Yugoslavia as "non-aligned". The contribution of the neutral States and of non-governmental organizations is what is lacking in the Middle East case.

The four neutrals: Finland, Sweden, Switzerland and Austria, were all "Western" by their value system and had multi-party forms of government, but they were not part of one of the two military alliances. Moreover, all four neutral States had a well-trained diplomatic corps which had participated in difficult negotiations before. They played a mediating role but also championed their own causes. Thus Switzerland pushed the concept of an OSCE Court, that could deal with the 
judicial settlement of disputes. The Court of Conciliation and Arbitration, though little used, is now located in Geneva.

Geneva also had a good number of representatives of non-governmental organizations (NGOs) who had consultative status with the United Nations and were concerned with arms control, human rights, conflict resolution and international trade agreements. While there was no formal structure for NGO contributions, through the U.N. there was access to diplomats of the countries involved. Two teaching colleagues of mine at the Graduate Institute of International and Development Studies in Geneva, Jean Siotis and Victor-Yves Ghebali, have written good accounts of the Geneva negotiations drawn largely from interviews and the vast number of working papers that were exchanged ${ }^{1}$.

Some seeds for a Middle East version of the
Helsinki process were planted but have not yet sprouted. The 1975 Helsinki Final Act has a chapter entitled "Questions relating to security and cooperation in the Mediterranean." The link between security in Europe and the Mediterranean has been formalized, starting in 1994, with the Mediterranean Partners for Cooperation: Algeria, Morocco, Tunisia, Egypt, Jordan, Israel. It is theoretically possible for leadership from these six States to propose an enlargement. Libya and Lebanon can also be considered "Mediterranean". One could also start with a totally new process - inspired by the example of the Helsinki process, but with no organic link.

The neutrals and Yugoslavia, in different ways, played important roles in the Helsinki process. There may be hidden visionaries in the Middle East who could give a start to such a process. Alas, for the moment their voices are mute and the situations grow more tense by the day. 